\title{
How Does New York Cultural Environment Impact Jewish Theater Production?
}

\author{
Jian $\mathrm{Su}^{1, *}$ \\ ${ }^{1}$ Vanke Meisha Academy, Shenzhen, Guangdong Province, China, 518000 \\ ${ }^{*}$ Corresponding author.Email: sujian@stu.vma.edu.cn
}

\begin{abstract}
The Jewish nation is an ancient nation, and the Jewish theater is an ancient cultural symbol. In contrast, New York is an international metropolis full of modern sense and fashion atmosphere. The collision between Jewish theater and the modern city is a topic worth exploring. This paper argues that in order to save the cultural heritage, it is necessary for Jewish directors and playwrights to produce theatres in Yiddish or Hebrew. In order to increase the acceptance of Jewish theater in the cultural environment of New York City, the creators of Jewish theater should broaden the subject matter and themes and include more entertainment. The biggest problem facing Jewish theater in New York is that Hebrew has fallen out of favor with Jewish youth, many of whom are no longer proficient in the language. This restricted the further development of Jewish theater in America.
\end{abstract}

Keywords: New York, Jewish Theater, Hebrew.

\section{INTRODUCTION}

The culture of a particular religion can be disclosed variously on a historical and modern stage. One significant perspective to view the development and transformation of religion is to see its arts. It was through the examination and analysis of frescos in Sistine Chapel that people detected how the nuances between the works on the ceiling and the Last Judgement reflected the Protestant Reformation.

In this view, the growth and adaptation of Jewish theater in New York provide a cultural insight for us to examine the misery of this story-like religion, Judaism. Although the term "theater" is used widely and frequently, the definition of it is quite arguable. I believe that the transformation of Jewish theater from their own lands to New York, caused by the two waves of development of Jewish theater in New York, results in crashes on the religious and cultural roots as well as the constricts on the creation of Jewish theater. To solve this, contemporary Jewish directors and playwrights are encouraged to produce theatrical works in Yiddish or Hebrew, which are believed to the Jewish languages, and also, Jewish creators should broaden their topics and themes and contain more entertainment instead of portraying reality, which is believed to be one distinct feature of Jewish theater.

\section{LITERATURE REVIEW}

Considering most of the different interpretations, in this research paper, "theater" is a live performance, including live actors and audience, according to professor Matthew Reason [1]. It is published in an academic article from a theater study journal. The definition helps scholars better identify the process of the transformation. Regarding of the main negative effect, it is doubtless that the new environment of Jewish theater crashes the religious and cultural roots. The mainstream value system in New York has broken traditional Jewish ethics. Life in New York lasts for many generations and then leads to a dangerous crisis of identity. Jews choose to abandon their religions. In this chain reaction, their theater production consequently loses Jewish ethics and values. The director of the play Angels in America, Tony Kushner, an American Jew, stated that as the newest generation of Jews in America, he did not know anything about Yiddish, Hebrew, and prayers [2]. It provides a third perspective to view the playwright's opinion toward traditions when he composed the theater. Beyond the work itself, the playwright's thought is also interesting. A rabbi that enters in the Act I Scene I of Angels in America says sadly at an older woman Sarah's funeral that she was the very last Judaist, and in a very soon time, all the Judaists will pass away; in the theater, the main 
character Louis points out that he is indifferent to the Judaism, for he thinks it is a suffocating rainy afternoon in March [3].

There is no doubt that the theater reflects two aspects of cultural loss. First, Jews have long lived on the margins of New York society, and both Christian and Islamic societies are forcing Jews to renounce their faith. An extended period of departure from their homeland, the absence of the past generation, and many other reasons do lead Jews to abandon their religion. They are seeking another faith, and ultimately, they choose the New York lifestyle. As a result, their lifestyle has been reflected in the theater, too. In such cases, the cultural heritage of religion may disappear forever[3].

Furthermore, the Jewish theater production becomes too singled-themed under the cruel treatment and attitude toward American Jews. Theater, an art form that can best illustrate real human life, becomes a great method to express American Jews' feelings and protests. The Jewish theater is constricted into a small range of social realism. After Elmer Rice, a Jewish American playwright, won the Pulitzer Prize for Drama, his social realistic theater production occupies most of the Jewish stage works: One of Elmer Rice's theater productions, Adding Machine, focuses on a man named Zero, an accountant at a normal company. After 25 years at his job, he discovers that he will be substituted by an adding machine [4]. In the postwar period, Jews generally appeared a phenomenon of confusion, indifference, fear, and alienation. They were nostalgic for traditions and did not know how to grasp the future. Many people live on the edge of society and cannot find a proper place. This kind of Jewish psychological state has become one of the essential themes reflected in New York or even the American Jewish theater as well as the whole American Jewish literature. In such a case, the single-themed theater production seems to be a repeated pattern under the constraint. As the leading figure of Jewish theater in New York, Elmer exerted great influence on the following playwrights as well as directors or other theater workers. He developed social realism to depict the hardships encountered by Jewish immigrants during their struggle in New York society. However, the following theater composers, such as Samuel Nathaniel Behrman and Clifford Odets, all follow his path and particularly follow the single theme of cruel treatment to Jewish Americans, which constricts and shrinks their topics and themes.

To better examine the whole process of transformation and adaption, we have a look at the two waves of development of American Jewish theater production. The first wave of the great transformation of Jewish theater from the traditional genre to New York brought creative authors to the city. After the outbreak of WWI, thousands of creative and passionate playwrights, actors, and directors who have learned theater production, especially those who were oppressed by the Tsar in Russia, came to in American Continent, and soon they started to plant their own culture, literature, and arts. Report news from The New York Times stated that started with Boris Thomashefsky, the very first Jewish star actor, the Jewish theater production in Yiddish rooted in New York in 1882 [5]. This report news is a centennial celebration of Jewish theater production rooted in New York that was released at that time. This article is from a well-known and creditable newspaper The New York Times. It helps people trace back to the very first landing of Jewish theater in New York with an exact record. Besides, Avram Goldfadn, the Russian Jewish playwright who was also recognized as the father of Jewish theater, took his company to NY at that time (MJL). This article is from a creditable website that focuses on the study of Jews and Judaism. It is a non-profit website that dedicates to preserving Jewish culture.

Looking at the historical factor, in 1882, a new wave of czarist oppression sent hundreds of thousands of Jews emigrating westward to America. Sandrow summarizes the total development of Jewish American performance artworks [7]. The first generation of Jewish Americans developed their theater works on stage with few audiences. Without much influence from local Americans and Jewish audiences, they established a system of original Jewish theater production. Actors, playwrights, directors, and producers gathered in the theaters in New York, put great efforts into creating arts, and waited for their very first audience.

Consequently, the very first passionate audience came at the second wave of the great transformation of Jewish theater from the traditional genre to New York. After WWII, Jewish immigrants from not only Russia but also Europe and Asia that came from different social classes constituted the majority of the audience of Jewish theater; they helped accomplish the second requirement of a live theater. The Jewish theater had a trend to absorb American culture. A statistic from an online museum reveals that, though estimates vary, nearly 220,000 European refugees settled in the US between 1933 and 1945 ("Refugees to the US from 1933-1945"). Jews of every class came to the theater: poor and unenlightened citizens were in the large amount, while the rich, the intelligent, and the broadminded were represented, too [8]. Hapgood offers a general overview of the psychological state of Jews. Chapter five specifically talks about the theater and audience of Jewish theater in New York [8]. WWII which had an even more comprehensive range caused another wave of immigration. As more and more Jewish immigrants come and reside in New York, those average citizens have less desire to preserve the old Jewish culture or revitalize their traditional faith. Instead, they call for social advancement and regard the 
Jewish theater in New York style as a course that would teach them to hasten their transformation from Jews to Americans. Thus, the creators who came earlier adapted their works and catalyzed the risk of being singlethemed. However, if we view the cultural loss from another perspective and consider some of the potential solutions, still the negative effects will not be significant problems.

\section{RESULTS \& DISCUSSION}

To save the cultural heritages, Jewish directors and playwrights are encouraged to produce theaters in Yiddish or Hebrew. Because Jewish theater producers have already abandoned their own culture, religions, and languages, they should again compose Jewish theater in ancient forms to recall who they are and prevent the identity crisis. Jewish theater in Yiddish offers the immigrant community a space to tackle the dilemmas between the new and old worlds, deal with fights of Jewish values and the shift to New York style, and find a middle area in its mother tongue and resonant language. There are famous plays such as Chantzhe in Amerika, which narrates the story of a Jewish immigrant woman who wants to drive, a Geburth Control by Harry Kalmanowitz [9]. It systematically illustrates the situation of American Jews after WWII and was written by a profound professor. It does give many examples and leading figures of American Jews in the theater field as well as their works. By combining various sides of old-world culture, American culture, and Jewish transitional culture, and by struggling with many of the immigrant quandaries of that Jewish culture, the Yiddish theater can help them reflect the truth and gain a better sympathy of their role in the history of reposition. Besides, it will give them better insight into the hitches of creating new identities in New York without abandoning their Jewish labels. With these being said, Jewish directors and playwrights are expected to produce theaters in Yiddish or Hebrew.

Jewish creators should broaden their topics and themes, and contain more entertainment instead of portraying the reality to raise the acceptance of Jewish theater in the New York culture environment. If the theater directors use comedies, funny and exaggerated actions to compose their works, more local New York residents will be attracted to watch. Even if the creators have a strong desire to express their protests and unfair treatments, a comic look can cover this single theme. The famous playwright Jacob Gordin implanted amusing and musical elements as a part of the Yiddish theater [9]. Although Samuel's Rain from Heaven reflects a somber subject, namely antisemitism, at the first glance it is a comedy, where all the main characters gather and play with each other [10]. Samuel's Rain from Heaven and Tony Kushner's Angels in America are all famous playscript that can best represent an age's style. Rain from Heaven is a drama about many key themes, including anti-Semitism, Communism, Capitalism, Idealism, Fascism, and Nazism. The dual expression in the play can help people better illustrate the image of American Jew's life. Similarly, Angels in America, a gay work on a national theme (Kushner), in addition to homosexuality and AIDS, deals with national themes such as contemporary American domestic politics and the crisis of religious belief. Although the play involves Judaism, it is not entirely about Judaism. When the Jewish theater first arrived in New York, playwrights were able to use elements of exaggeration and explore different styles. But with the outbreak of war and the rise of antisemitism, theater becomes a vehicle for expression, not a mere art. Some dramatic works prove that when the whole play is not merely about a single theme, it tends to be welcomed by more audiences, especially by residents.

Moreover, from a critical point of view, the potential solutions still have several weaknesses. The Jewish audience calls for a liberal theater production with multiple themes and topics after the assimilation process. The Yiddish or Hebrew theaters will not find their markets. The fleeing Jews have initially been calling for equality. This strong desire for freedom is combined with the inherent liberalism and pluralistic democracy in American culture, which makes American Jewish culture show a very strong open-mindedness. Sarah Benor, a linguistic expert, addressed that American Jews are generally able to speak an English indistinguishable from that of non-Jews, and because of secularization, Hebrew and Aramaic now play a less central role in Jewish life [11]. She researched the current usage of the traditional Jewish language Hebrew and Yiddish and revealed the truth that seldom young Jews in America use these two languages. The audiences of Jewish theater are more likely to choose American cultural stuff, not only for they have been profoundly influenced by that, but also for they are seeking for that life pattern to better be a part of the American community. On the opposite, the language differences have led to great prejudices and discriminations, which may not be a decent way to combine with Jewish theater. Jewish theater needs to figure out another way to save the cultural and religious roots. The young generations are more likely to buy tickets for "American" Broadway shows, but not the traditional Jewish theater that will label them as Jews.

In addition, the original single-themed pattern offers a great chance for developing expressionism, which has less necessity to change. Due to the prejudices, discriminations, and antisemitism, theater directors create a euphemistic expression to show their protests, which we call expressionism. They use plenty of symbols and metaphors to indicate what they want to state in theaters. A lot of symbols are used in the Adding Machine, the characters' personalities are 
ambiguous, and many characters only have code names, which symbolize the universality and commonness of these characters and are unknown to the public. The same trait can be detected in Samuel's Rain from Haven and Clifford's Awake and Sing. The image and encounter of Mr. Zero reveal the tragic fates of the ordinary Jews represented by him in modern society. It is acceptable to portray the reality but in expressionism, a way to immerse deeply into the political, social, and economic materials of the new cultural environment. Using symbols and metaphors in a theater can lead the whole story to a more insightful level. It has already created a trend of expressionism in the Jewish theater circle. In the 1930s and 1940s, when Hitler and fascism rose to power, and even until today, expressionism is the only and the best way to describe Jewish life.

\section{CONCLUSION}

All in all, the transformation of Jewish theater from their own lands to New York, caused by the two waves of development of Jewish theater in New York, results in the crashes on religious and cultural roots as well as the constricts on the creation of Jewish theater. To solve this, Jewish directors and playwrights are expected to produce theater in Yiddish or Hebrew, and also Jewish theater artists should broaden their topics and themes, and contain more entertainment instead of portraying reality. New York is the center for Jewish culture in America, while theater is the sum of history and life pattern, so the research on the Jewish theater in New York can help us best review how the Jews immigrated to other lands, how they maintain their own Jewish culture, and how they explore and combine with new American culture. Whether the Jewish theater abandons its original culture or not is the inevitable trend of human development and an integrated community, so time will see how it eventually comes up on stage.

\section{REFERENCES}

[1] Reason, Matthew. "Young Audiences and Live Theatre, Part 2: Perceptions of Liveness in Performance." Studies in Theatre and Performance, vol. 26, no. 3, 2006, pp. 221-241.,

[2] Glenn, Lane. A. "Angels in America." Drama for Students. Gale Literary Group, (1999).

[3] Kushner, Tony. "Angels in America." The Longman Anthology of Drama and Theater: a Global Perspective. Edited by Michael L. Greenwald, Pearson Longman, 2004.

[4] Rice, Elmer. The Adding Machine: A Play in Seven Scenes. S. French, (1956).

[5] Chira, Susan. "100 YEARS OF YIDDISH THEATER CELEBRATED." The New York Times, 15 Oct. (1982), pp. 28, https://www.nytimes.com/1982/10/15/theater/100years-of-yiddish-theater-celebrated.html.

[6] Mjl. "Jewish Theater." My Jewish Learning, www.myjewishlearning.com/article/jewish-theatre.

[7] Sandrow, Nahma and Cohen, Sarah B. From Hester Street to Hollywood: the Jewish American Stage and Screen. 1st Midland book ed., vol. 1, Indiana Univ. Pr., 1986.

[8] Hapgood, Hutchins. The Spirit of the Ghetto. Edited by Moses Rischin, Belknap Press of Harvard Univ. Press, 1983.

[9] Shapiro, Edward S. A Time for Healing: American Jewry since World War II. Vol. 5, Johns Hopkins University Press, 1992.

[10] Behrman, Semuel N. Rain from Heaven. Kessinger Publishing, 2006.

[11] Benor, Sarah Bunin. "Do American Jews Speak a 'Jewish Language'?--A Model of Jewish Linguistic Distinctiveness.” Jewish Quarterly Review, vol. 99, no. 2, 2009, pp. 230-269. 